This is an author produced version of a paper published in Agriculture Ecosystems and Environment. This paper has been peer-reviewed and is proof-corrected, but does not include the journal pagination.

Citation for the published paper:

Kätterer, T., Bolinder, M. A., Andrén, O., Kirchmann, H., Menichetti, L. (2011) Roots contribute more to refractory soil organic matter than aboveground crop residues, as revealed by a long-term field experiment.

Agriculture Ecosystems and Environment.

Volume: 141 Number: 1-2, pp 184-192.

http://dx.doi.org/10.1016/j.agee.2011.02.029

Access to the published version may require journal subscription.

Published with permission from: Elsevier

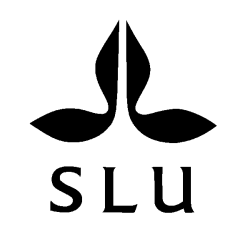

Epsilon Open Archive http://epsilon.slu.se 


\title{
Roots contribute more to refractory soil organic matter than aboveground crop residues, as revealed by a long-term field experiment
}

\author{
Thomas Kätterer*, Martin Anders Bolinder, Olof Andrén, Holger Kirchmann and Lorenzo Menichetti \\ Swedish University of Agricultural Sciences (SLU), Department of Soil and Environment, Box 7014, 75007 Uppsala, Sweden
}

Corresponding author: Thomas.Katterer@slu.se

\begin{abstract}
We revisited the well documented and ongoing long-term 'Ultuna continuous soil organic matter field experiment' which started in 1956 at the Swedish University of Agricultural Sciences. The objective of the experiment is to quantify effects of six organic amendments and mineral $\mathrm{N}$ fertilizers on the crop and soil. We used the 'equivalent soil mass' concept for estimating changes in the topsoil $\mathrm{C}$ stocks in all 15 treatments. $\mathrm{C}$ inputs from amendments were measured and those from crops were calculated using allometric functions and crop yields. Clustering $\mathrm{C}$ inputs into seven categories by quality allowed us to calculate a 'humification' coefficient for each category. Here, these coefficients simply were based on the fraction of total $\mathrm{C}$ input that still remains in the topsoil after about 50 years. As indicated by previous studies, this coefficient was highest for peat, followed by sewage sludge, manure, sawdust and aboveground crop residues. The most interesting result from the current investigation is that the optimized coefficient for rootderived $\mathrm{C}$ was about 2.3 times higher than that for aboveground plant residues. The calculated results were found to be robust in a sensitivity analysis. Our findings strongly support the hypothesis that root-derived $\mathrm{C}$ contributes more to relatively stable soil $\mathrm{C}$ pools than the same amount of aboveground crop residue-derived C.
\end{abstract}

Keywords: Carbon sequestration, equivalent soil mass, humification coefficient, long-term field experiment, roots

\section{Introduction}

Cropland management aiming at $\mathrm{C}$ sequestration in soils has considerable mitigation potential (IPCC 2007; Lal and Follet, 2009). However, our understanding of the conversion of crop residues into soil organic material is still limited and has been suggested as a prioritized research topic (Andrén et al., 2008; Lal, 2009). The fraction of crop residues converted into more stabilized soil organic material, the 'humification coefficient', is a substrate quality parameter in most soil organic C models. Pioneer work by Hénin and Dupuis (1945) led to a definition of the humification coefficient of added organic material as the fraction converted to more resistant soil organic matter.

The humification coefficients $(h)$ associated with the Hénin and Dupuis (1945) model are 0.30 (i.e., $30 \%$ ) for farmyard manure, and 0.08 and 0.10 for maize and small-grain cereal straw, respectively. For roots of maize and small-grain cereals, Hénin and Dupuis (1945) provided a coefficient of 0.15 , which is higher than that for aboveground residues. Over the years, these coefficients have been subject to several modifications. For example, Plénet et al. (1993) set $h$ for shoots to $0.055-0.065$ and that for roots to 0.16 0.30 . However, the original $h$ for manure given by Hénin and Dupuis (1945) was supported by studies of Delas and Molot (1983) and Boiffin et al. (1986). Over the years, the expression and calculation of $h$ has been subject to modifications (e.g., Janssen, 1984).

There are different methodologies that can be used to estimate humification of shoots and roots. For instance, there are long-term field experiments where aboveground residues are either returned to the soil or removed after harvest and the results compared with a bare soil treatment (Barber, 1979; Delas and Molot, 1983; Larson et al., 1972; Plénet et al., 1993). It is also possible to use ${ }^{13} \mathrm{C}$ natural abundance techniques (e.g., Bolinder et al., 1999). Incubation studies with the mixing of plant residues into soil and/or in litter-bags in association with ${ }^{13} \mathrm{C}$ and ${ }^{14} \mathrm{C}$ labelling techniques are another option (see review by Rasse et al. 2005). Another possibility that has been explored is to estimate humification indirectly from biochemical properties of crop residues. For example, Linères and Djakovitch (1993) proposed that a Biological Stability Index (BSI) computed from lignin plus cutin, crude fiber, hemicellulose, and soluble fractions can be used as a proxy in the Hénin and Dupuis (1945) model. BSI has been used to characterize different organic materials including crop residues (e.g., Parent et al., 2010), but as any chemical proxy used to predict a biologically mediated process it has a limited generality.

In recent years, the preferential preservation of root $\mathrm{C}$ compared with shoot $\mathrm{C}$ (higher $h$ ), which was actually included in the original work by Hénin and Dupuis (1945), has been re-emphasized by several authors (e.g., Bolinder et al., 1999; Wilhelm et al., 2004; Rasse et al., 2005; Johnson et al., 2006). Rasse et al. (2005) and Johnson et al. (2006) expand on the concepts and possible mechanisms involved. A key topic related to this issue is the amount of belowground $\mathrm{C}$ inputs attributed to extra-root $\mathrm{C}$. The extraroot $\mathrm{C}$ can be defined as turnover and cell sloughing of epidermal root tissues during the growing season, and soluble compounds released from the roots by exudation (see Hansson and Steen (1984) and Andrén et al. (1989) for principles). Common assumptions are that this extra-root $\mathrm{C}$ is equivalent to about 65 to $100 \%$ of the measurable root biomass (Bolinder et al., 1999; 
2007; Rasse et al., 2004; Plénet et al., 1993). However, the contribution of extra-root $\mathrm{C}$ to more resistant soil organic matter is an open issue (e.g., Grace et al. 2006). This $C$ input has been claimed to delay decomposition of crop residues and native soil organic matter, or accelerate or 'prime' the decomposition rate of both crop residues and other organic $\mathrm{C}$ present in the rhizosphere (see Wilhelm et al. (2004), Johnson et al. (2006) and Fontaine et al. (2007) and references cited therein).

It can be argued that in situ measurements in longterm field experiments are superior over other methods for quantifying humification values, because insignificant annual changes accumulate over time under natural conditions and eventually become detectable. There are only a few long-term field experiments with detailed soil- and crop records available, in which the overall quality of measurements enables to analyze changes with sufficient precision. For instance, there has not always been enough consideration of soil bulk density dynamics, changes in topsoil depth and other confounding factors (cf. Andrén et al., 2008). Using C or soil organic matter analyses and conversions between these can also introduce errors (Boiffin et al., 1986).

To our knowledge, no studies are published that have used the concept of equivalent soil mass in association with the estimation of humification. In this study, we revisited the well documented and ongoing long-term 'Ultuna continuous soil organic matter field experiment' that started in 1956 . Our objective was to test the hypothesis that roots contribute more to soil $\mathrm{C}$ than an equal amount of aboveground crop residues. This was analyzed for different organic amendments and crop residues when accounting for all in- and outputs of matter as well as changes in bulk density and topsoil depth over time.

\section{Material and methods}

\subsection{Site description}

The 'Ultuna long-term soil organic matter experiment' was started in 1956 at the Swedish University of Agricultural Sciences (SLU) close to Uppsala (59.82 $\left.{ }^{\circ} \mathrm{N}, 17.65{ }^{\circ} \mathrm{E}\right)$. The field has been in agriculture for probably several hundreds of years. The climate is cold temperate and subhumid with an annual (19562009) mean air temperature of $5.8{ }^{\circ} \mathrm{C}$ and an annual mean total precipitation of $542 \mathrm{~mm}$. The topsoil $(0-20$ $\mathrm{cm})$ is a clay loam with $36.5 \%$ clay, $41 \%$ silt $(0.002-$ $0.06 \mathrm{~mm})$ and $22.5 \%$ sand $(0.06-2 \mathrm{~mm})$ and has been classified as a Typic Eutrochrept (USDA soil taxonomy) or Eutric Cambisol (FAO, 1989) (Kirchmann et al., 1996). At the start of the experiment, soil $\mathrm{pH}$ was 6.5 . To avoid soil creeping between plots $(2 \times 2 \mathrm{~m})$, adjacent plots are separated with frames that originally extended about $30 \mathrm{~cm}$ into the soil and about $10 \mathrm{~cm}$ above the soil surface.

The original aims of the experiment were to investigate the long-term effect of mineral $\mathrm{N}$ fertilizers and different organic amendments on crop yields, soil organic matter changes and soil physical properties. The experiment consists of 15 treatments replicated in four blocks (Table 1). Approximately similar amounts of $\mathrm{C}$ are added in ten of the treatments biannually as different organic amendments such as straw, green manure, farmyard manure, sawdust, peat and sewage sludge. Since three treatments receive inorganic N fertilizers only, six receive organic amendments only, four receive both and one receives neither nor,

Table 1. Treatments (4 replicates) in the Ultuna long-term soil organic matter experiment, type of $\mathrm{N}$ fertilizer and organic amendments applied to plots, $\mathrm{C}$ concentrations, bulk density $\left(\rho ; \mathrm{Mg} \mathrm{m}^{-3}\right), \mathrm{pH}$, elevation relative to the bare fallow measured in 2009, equivalent topsoil depth $\left(z_{e q}\right)$ in 2009 calculated from mass balances (see text) and soil organic carbon content to equivalent topsoil depth. Std. stands for standard deviation. Means suffixed by different letters are significantly different at $\mathrm{P}<0.05$ according to Tukey's Studentized Range test.

\begin{tabular}{|c|c|c|c|c|c|c|c|c|c|c|c|c|}
\hline \multirow[t]{2}{*}{ ID } & \multirow[t]{2}{*}{ Tre atment } & Fertilize $^{\mathrm{a}}$ & \multirow{2}{*}{$\begin{array}{l}\text { O rganic amend } \\
\left.\mathrm{y} \mathrm{r}^{-1}\right)\end{array}$} & \multicolumn{2}{|c|}{ C \% } & \multicolumn{2}{|c|}{ Bulk density } & \multicolumn{2}{|c|}{$\mathbf{p H}\left(\mathrm{H}_{2} \mathbf{O}\right)$} & \multirow{2}{*}{$\begin{array}{l}\text { Relative } \\
\text { elevation } \\
\text { (cm) } \\
\end{array}$} & \multirow{2}{*}{$\begin{array}{c}z_{e q} \\
(\mathbf{c m})\end{array}$} & \multirow{2}{*}{$\begin{array}{l}\text { C stock } \\
\text { Mg ha }^{-1}\end{array}$} \\
\hline & & $\mathrm{kg} \mathrm{Nha}^{-1} \mathrm{y}$ & & Mean & Std. & Mean & Std. & Mean & Std. & & & \\
\hline $\bar{a}$ & Bare fallow & & & $0.97^{\mathrm{i}}$ & 0.03 & $1.43^{\mathrm{a}}$ & 0.06 & $6.14^{\mathrm{ef}}$ & 0.16 & $0.00^{\mathrm{a}}$ & 19.5 & 27.2 \\
\hline $\mathrm{b}$ & Control & & & $1.12^{\mathrm{hi}}$ & 0.04 & $1.40^{\mathrm{ab}}$ & 0.02 & $6.23^{\mathrm{def}}$ & 0.08 & $0.2^{\mathrm{a}}$ & 20 & 31.5 \\
\hline $\mathrm{c}$ & Calcium nitrate & $\mathrm{Ca}\left(\mathrm{NO}_{3}\right)_{2}$ & & $1.37^{\mathrm{gh}}$ & 0.06 & $1.28^{\mathrm{bcd}}$ & 0.04 & $6.69^{\mathrm{c}}$ & 0.07 & $0.4^{a b c}$ & 21.9 & 37.8 \\
\hline d & Ammonium sulfate & $\left(\mathrm{NH}_{4}\right)_{2} \mathrm{SO}_{4}$ & & $1.25^{\mathrm{ghi}}$ & 0.02 & $1.21^{\mathrm{de}}$ & 0.06 & $4.14^{\mathrm{i}}$ & 0.12 & $2.1^{\mathrm{abc}}$ & 23 & 34.1 \\
\hline e & Calcium Cyanamid & $\mathrm{CaCN}_{2}$ & & $1.43^{\mathrm{gh}}$ & 0.03 & $1.25^{\mathrm{cd}}$ & 0.04 & $7.24^{\mathrm{a}}$ & 0.07 & $2.1 \mathrm{abc}$ & 23.3 & 38.9 \\
\hline$f$ & Straw & & straw & $1.49^{\mathrm{g}}$ & 0.03 & $1.38^{\mathrm{ab}}$ & 0.07 & $6.36^{\text {cde }}$ & 0.06 & $1.0^{\mathrm{abc}}$ & 20.8 & 41.8 \\
\hline $\mathrm{g}$ & Straw $+\mathrm{N}$ & $\mathrm{Ca}\left(\mathrm{NO}_{3}\right)_{2}$ & straw & $1.92^{\mathrm{ef}}$ & 0.07 & $1.21^{\mathrm{de}}$ & 0.01 & $6.63^{\mathrm{bc}}$ & 0.09 & $1.3^{\mathrm{ab}}$ & 23.4 & 50.9 \\
\hline $\mathrm{h}$ & Green manure & & grass & $1.54^{\mathrm{g}}$ & 0.04 & $1.34^{\mathrm{abc}}$ & 0.02 & $6.07^{\mathrm{ef}}$ & 0.09 & $1.4^{\mathrm{ab}}$ & 21.2 & 43 \\
\hline $\mathrm{i}$ & Peat & & peat & $3.18^{\mathrm{b}}$ & 0.4 & $1.12^{\mathrm{ef}}$ & 0.02 & $5.53^{\mathrm{g}}$ & 0.13 & $3.5 \mathrm{abc}$ & 25.2 & 84 \\
\hline j & Farmyard manure & & farmyard manure & $2.21 \mathrm{~d}^{\mathrm{e}}$ & 0.11 & $1.24^{\mathrm{cde}}$ & 0.04 & $6.48^{\mathrm{bcd}}$ & 0.06 & $2.6^{\mathrm{abc}}$ & 23.2 & 59 \\
\hline $\mathrm{k}^{\mathrm{b}}$ & Farmyard manure & $\mathrm{CaCN}_{2}$ & farmyard manure & $2.26^{\mathrm{d}}$ & 0.02 & $1.20^{\mathrm{de}}$ & 0.04 & $6.29^{\mathrm{def}}$ & 0.1 & $2.3^{b c}$ & 23.8 & 62.6 \\
\hline 1 & Sawdust & & sawdust & $1.86^{\mathrm{f}}$ & 0.07 & $1.28^{\mathrm{bcd}}$ & 0.05 & $6.31^{\mathrm{de}}$ & 0.11 & $1.6^{\mathrm{abc}}$ & 22.3 & 51.1 \\
\hline $\mathrm{m}$ & Peat $+\mathrm{N}$ & $\mathrm{Ca}\left(\mathrm{NO}_{3}\right)_{2}$ & peat & $3.78^{\mathrm{a}}$ & 0.14 & $1.05^{\mathrm{f}}$ & 0.04 & $5.99^{\mathrm{f}}$ & 0.15 & $4.9^{c}$ & 26.3 & 96.9 \\
\hline $\mathrm{n}$ & Sawdust $+\mathrm{N}$ & $\mathrm{Ca}\left(\mathrm{NO}_{3}\right)_{2}$ & sawdust & $2.20^{\mathrm{de}}$ & 0.1 & $1.23^{\mathrm{cde}}$ & 0.08 & $6.67^{\mathrm{b}}$ & 0.1 & $2.5^{a b c}$ & 23.1 & 58.6 \\
\hline o & Sewage sludge & & sewage sludge & $2.66^{\mathrm{c}}$ & 0.11 & $1.02^{\mathrm{f}}$ & 0.06 & $4.89^{\mathrm{h}}$ & 0.08 & $5.7^{\mathrm{c}}$ & 27 & 69.9 \\
\hline
\end{tabular}

${ }^{\mathrm{b}}$ Calcium Cyanamid was applied in K only in 1956. Manure applications in 1956 and 1960 derived from different batches in K and J. Total applications of $\mathrm{N}$ were about $60 \mathrm{~kg}$ higher in $\mathrm{K}$ than $\mathrm{J}$ during that time period. Thereafter, the only differences between $\mathrm{K}$ and $\mathrm{J}$ were double $\mathrm{P}$ application (superphosphate) in $\mathrm{K}$ compared to $\mathrm{J}$ and all other treatments 
Table 2. Frequency of crops (number of years) in the experiment and relative allocation of crop $\mathrm{C}$ into roots, including rhizodeposition, according to Bolinder et al. (2007).

\begin{tabular}{|c|c|c|}
\hline Crop & Number of years & Root allocation coefficient $\left(R_{R E}\right)$ \\
\hline Spring barley & 17 & 0.149 \\
\hline Oats & 11 & 0.398 \\
\hline Silage maize & 10 & 0.228 \\
\hline Other crops ${ }^{\mathrm{a}}$ & 10 & 0.228 \\
\hline Wheat ${ }^{b}$ & 3 & 0.196 \\
\hline Crop failure & 3 & \\
\hline Total 1956-2009 & 54 & \\
\hline
\end{tabular}

differences in crop yields are considerable and increasing over time. Average total dry matter yields (excluding three years with crop failure) were for example $3.3 \mathrm{Mg} \mathrm{ha}^{-1}$ in the unfertilized control, 6.5 $\mathrm{Mg}$ in the calcium nitrate fertilized treatment and 8.1 $\mathrm{Mg}$ in the sewage sludge amended treatment, which delivered the highest yields. A bare fallow treatment, which is regularly weeded manually, except for a single application of glyphosate in 1991, is included. Weed biomass production has not been quantified, but approximated to be less than $50 \mathrm{~kg}$ dry mass $\mathrm{ha}^{-1}$ year

Oats were grown over the whole trial in 1956 and harvested separately in each plot. Total aboveground dry matter yield (on average over treatments) in 1956 (grain and straw) was $7.29 \mathrm{Mg} \mathrm{ha}^{-1}$ and the relatively low standard deviation $\left(0.27 \mathrm{Mg} \mathrm{ha}^{-1}\right)$ indicates quite homogenous site conditions. The crop rotation between 1957 and 1999 was dominated by spring cereals (Table 2). During the last ten years, silage maize was grown. Each spring, all treatments including the bare fallow receive a dressing of $20 \mathrm{~kg} P$ $\mathrm{ha}^{-1}$ as superphosphate and $35-38 \mathrm{~kg} \mathrm{~K} \mathrm{ha}^{-1}$ as $\mathrm{KCl}$. A more detailed description of the experiment and results for the first 35 years was presented by Kirchmann et al. (1994) and Persson and Kirchmann (1994). Earlier time series of $\mathrm{C}$ data for selected treatments have been used for calibrating and validating different soil C balance functions and models (Parton et al., 1983; Paustian et al., 1992; Hyvönen et al., 1996; Witter, 1996; Andrén and Kätterer, 1997; Kätterer and Andrén, 1999; Petersen et al., 2005; Juston et al.,
2010; Barré et al., 2010).

\subsection{Soil sampling and analysis}

Soil sampling (0-20 cm depth) was carried out in autumn (September to November), intermittently between 1956 and 1983, and biannually thereafter. The most recent sampling was performed in September 2009 (Table 1). Sampling was done after harvest, and after all crop residues had been cut at the soil surface and removed. The soil was sampled using a soil corer at five random locations in each plot which were combined to one composite sample per plot before analysis. Methods and laboratory equipment for $\mathrm{C}$ analysis have changed over the years, from loss on ignition and wet combustion (Walkley Black) to dry combustion methods (Ströhlein instruments and different LECO instruments since the 1990s). Therefore, we tested the consistency of the C concentration data in our database by comparing these measurements with those presented by Gerzabek et al. (1997), who re-analyzed archived soil samples from five treatments for the period 1956 to 1993 using an element analyzer (Carlo Erba 1500).

In September 2009, we also sampled the depth layers $0-10$ and $10-20 \mathrm{~cm}$ in all plots for determining bulk density, using cylinders $7.2 \mathrm{~cm}$ in diameter and $10 \mathrm{~cm}$ height. Together with previous measurements, we created a bulk density time series for each treatment using regression analysis.

2.3. Determination of mineral mass balance and equivalent topsoil depth

Differences in soil surface elevation between plots are visible. To quantify these, we calculated the mass balance of soil mineral matter $\left(M_{\text {min }} ; \mathrm{Mg} \mathrm{ha}^{-1}\right)$ for each treatment and year $(t)$ according to the equation:

$$
\begin{aligned}
& M_{\text {min }}(t)=M_{\text {min }}(t-1)+M_{\text {amendment }}(t-1)-M_{\text {sampling }}(t-1) \\
& -M_{\text {harvest }}(t)
\end{aligned}
$$

where $M_{\text {amendment }}$ is the mineral mass added in the organic amendments, and $M_{\text {sampling }}$ and $M_{\text {harvest }}$ are the that exported through soil sampling or crop harvest, respectively. The initial value for soil mineral matter (in $\mathrm{Mg} \mathrm{ha}^{-1}$ ) down to $20 \mathrm{~cm}$ depth in 1956 is:

$$
M_{\min }(1956)=\rho(1956) *(100-S O M \%) * 20
$$

\begin{tabular}{|c|c|c|c|c|c|}
\hline Type of amendment & Dry mass applied & Organic fraction of dry mass & $\mathrm{C}$ in organic fraction & C applied & $M_{\text {amendment }}$ \\
\hline & $\left(\mathrm{Mg} \mathrm{ha}^{-1} \mathrm{yr}^{-1}\right)$ & & $\%$ & $\left(\mathrm{Mg} \mathrm{ha}^{-1} \mathrm{yr}^{-1}\right)$ & $\left(\mathrm{Mg} \mathrm{ha}^{-1} \mathrm{yr}^{-1}\right)$ \\
\hline Straw & 4.21 & 0.905 & 46.5 & 1.77 & 0.28 \\
\hline Green manure & 4.23 & 0.902 & 46.2 & 1.76 & 0.29 \\
\hline Peat & 3.96 & 0.971 & 51.3 & 1.97 & 0.08 \\
\hline Manure & 4.75 & 0.799 & 50.4 & 1.9 & 0.67 \\
\hline Sawdust & 3.87 & 0.989 & 48.1 & 1.84 & 0.03 \\
\hline Sewage sludge & 6.43 & 0.562 & 50.8 & 1.84 & 1.97 \\
\hline
\end{tabular}




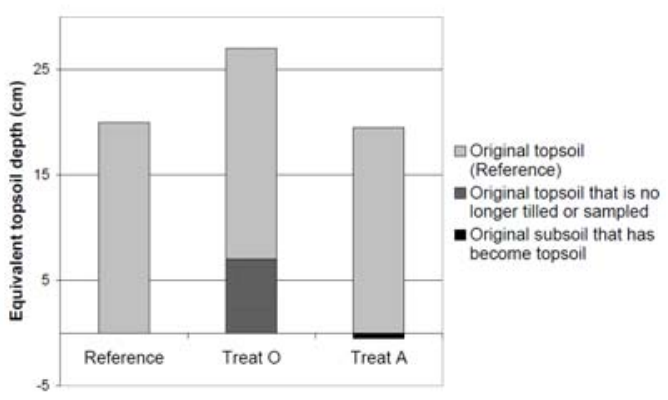

Fig. 1. Illustration of the equivalent topsoil depth concept. Soil depth has increased over time in the sewage sludge treatment (treatment $\mathrm{O}$ ) due to declining bulk density, increase in carbon mass and a positive mineral mass balance. In the bare fallow (treatment A) soil depth declined mainly due to soil sample export and decline in carbon mass.

where $\rho$ is bulk density and the soil organic matter concentration $(S O M=\mathrm{C} / 0.5)$ was assumed to contain $50 \%$ C (Pribyl, 2010). $M_{\min }$ inputs from atmospheric deposition which probably did not differ much between treatments and mineral fertilizers were assumed to be counterbalanced by leaching and export in harvested products. However, the amount of silicon exported with harvest products $\left(M_{\text {harvest }}\right)$ may not be negligible. It is well known that the silica content in biomass varies greatly between species, plant parts and physiological stage (Lanning et al., 1980; Filya, 2004) but is mainly correlated with dissolved Si in soil solution (Jones and Handreck, 1967). According to a Swedish study (Hadders et al., 2001), the ash content in cereal grains (wheat, rye, barley, oats) was, on average, about $25 \mathrm{mg} \mathrm{g}^{-1}$. In the same investigation, silica concentrations in ashes varied between 0 and $43 \%$ and were positively correlated with soil clay content. Due to the relatively high clay content in our experiment, we assumed the silica portion of the ash in grains to be $40 \%$, which corresponds to $10 \mathrm{mg}$ per gram grain dry matter. For exported straw, we used the mean ash content (96 mg per gram) as measured in the straw added as an amendment (23 samples) to treatments $\mathrm{F}$ and $\mathrm{G}$. This ash content is higher than that reported in some Scandinavian studies (Olanders, 1995; Sander, 1997; Jensen et al., 1998) but similar to those in other studies (Jackson, 1977; Pan and Sano, 2005). Based on known concentrations of other oxides in the ash, we estimated that a silica concentration in straw ash of $70 \%$ should be reasonable. The same silica concentration was assumed in the ash of added straw and all other organic amendments for calculating $M_{\text {amendment }}$ (Table 3). For silage maize and other forage crops we assumed an ash content of $40 \mathrm{mg} \mathrm{g}^{-1}$ as reported for silage maize (Filya, 2004) and a silica content of $25 \mathrm{mg} \mathrm{g}^{-1}$.

In order to calculate the equivalent depth of $M_{\text {soil }}$ (1956) in the different treatments over time, we applied the principle of equivalent soil mass (Nye and Greenland, 1964; Jenkinson and Johnston, 1976; Jenkinson et al., 1992) taking into account differences in bulk densities and $\mathrm{C}$ concentration in the different soil layers (Fig. 1)
Since bulk density, C content, and topsoil depth differed between experimental treatments, the depth of $M_{\text {soil }}(\mathrm{t})$ is not directly proportional to the mass ratio $M_{\text {min }}(1956) / M_{\text {min }}(\mathrm{t})$, but must be scaled according to these simultaneous changes in bulk density and $\mathrm{C}$ concentration in each layer. Thus, the equivalent topsoil depth $\left(z_{e q}\right)$ was calculated from the mass balance equation which has to be solved for each year.

$M_{\min }(1956)=\int_{z=0}^{z_{c q}} M_{\min }(t) d z$

In the years for which no measurements were available, a linear or log-linear interpolation between measurements to calculate $\mathrm{C}$ concentrations and bulk densities for the layer $0-20 \mathrm{~cm}$ was used, respectively (see also above). Subsoil data are few due to sampling restrictions given by the small plots. Estimates are only available for $1956\left(\rho=1.49 \mathrm{~g} \mathrm{~cm}^{-3}\right.$ at $20-30 \mathrm{~cm}$ depth; Eriksson, 1980) and for 1997 (Bergkvist et al., $2003)$ in treatment $\mathrm{C}\left(\rho=1.41 \mathrm{~g} \mathrm{~cm}^{-3}\right.$ at $20-25 \mathrm{~cm}$ depth) and in treatment $\mathrm{O}\left(\rho=1.30 \mathrm{~g} \mathrm{~cm}^{-3}\right.$ at $20-25 \mathrm{~cm}$ and $\rho=1.49 \mathrm{~g} \mathrm{~cm}^{-3}$ at $25-30 \mathrm{~cm}$ depth). We used the bulk density measurement for treatment $\mathrm{O}$ in all cases where $z_{e q}>20 \mathrm{~cm}$. To calculate $\mathrm{C}$ concentrations below $20 \mathrm{~cm}$ we used linear interpolation between $\mathrm{C}$ concentrations in $1956(1.6 \% \mathrm{C}$; Bergkvist et al., 2003) and treatment-specific values determined in 2009 , which varied between 0.9 and $2.1 \% \mathrm{C}$ in $\mathrm{A}$ and $\mathrm{M}$, respectively (unpublished data).

The accumulated export of soil from each $2 \times 2 \mathrm{~m}$ plot due to sampling ( $\left.M_{\text {sampling }}\right)$ was estimated. This export was estimated from notes in our archived files, though other, more or less authorized samplings have been performed and not documented properly. Generally, sampling intensity increased with time and was most intensive during the $1990^{\text {ies }}$. Before 1974, soil samples were taken in 1967 and thereafter biannually. For the ordinary bi-annual sampling, we use an auger with $2 \mathrm{~cm}$ diameter. Thus, with five samples down to $20 \mathrm{~cm}, 0.314 \mathrm{dm}^{-3}$ of soil per plot is removed which corresponds to a subsidence of the soil surface of about $0.08 \mathrm{~mm}$ at each ordinary sampling occasion. Since 1990 the soil was sampled more frequently and intensively for many different studies, although some samples were brought back to the field after analysis. We tried to account for this in our balance as accurately as possible.

\subsection{Measurements of soil surface elevation}

The elevation of the experimental plots was measured 29 September 2009 at 12 locations within each plot in a regular grid using an optical leveling instrument. The rationale for measuring elevation was to obtain an independent measurement for $z_{e q}$. The experimental area is situated on slightly sloping plain of post-glacial sediments. Elevation measurements around the experimental area showed a slope of about $1 \%$, more or less diagonally through the experiment. However, this slope was not entirely consistent throughout, so a treatment comparison using absolute height measurements was not found to be reliable. Instead, we calculated relative height differences between adjacent experimental plots and compared the average 
elevation of each plot with that from its five nearest neighbors, or three for those plots located at the border of the experiment (198 comparisons in total). The elevation differences were weighted according to the inverse distance between the centers of each plot. Before analyzing these differences per treatment, mean values were calculated over those comparisons that occurred more than once in the data set. The resulting data set, which contained 142 comparisons, between 8 and 12 per treatment, was subjected to analysis of variance.

\subsection{Calculation of $C$ stocks}

$\mathrm{C}$ stocks to equivalent soil depth $\left(\mathrm{Mg} \mathrm{ha}^{-1}\right)$ were calculated for the years where $\mathrm{C}$ concentrations measurements were available using $\rho(t)$ and $z_{e q}(t)$ as calculated using the mineral mass accounting approach described above:

$$
C_{\text {topsoil }}(t)=\int_{z=0}^{z_{\text {eq }}(t)} \rho(t) C \%(t) d z
$$

\subsection{C input from organic amendments}

The organic amendments were added in autumn and carefully worked into the topsoil down to $20 \mathrm{~cm}$ depth using a spade. All aboveground material was removed before adding the organic amendments. Amendments were applied 1956, 1960 and 1963 and thereafter every second year. In 1956 and 1960, the applications were based on equal dry mass. All following applications were based on equal amounts of ash-free organic mass amounting to $8 \mathrm{Mg} \mathrm{ha}^{-1}$ applied every

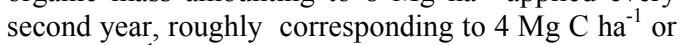
$2 \mathrm{Mg} \mathrm{C} \mathrm{ha}{ }^{-1}$ per year. For a more precise estimate of C input, we measured the $\mathrm{C}$ concentrations in the different amendments from four different years. Average $\mathrm{C}$ concentrations in the organic fractions varied from $48.1 \%$ in straw to $50.8 \%$ in sewage sludge (Table 3). Thus, $\mathrm{C}$ applications in the different treatments varied between 3.76 and $4.10 \mathrm{Mg} \mathrm{C} \mathrm{ha}^{-1}$. These differences in $\mathrm{C}$ inputs were accounted for in our calculations.

\subsection{Carbon input from current crops}

Aboveground crop residues are removed after cutting the plants just above the soil surface. Thus, crop residues entering the soil are mostly stem-bases, i.e., below-ground parts of stems, roots and rhizosphere deposits. Linear functions and parameter values proposed by Bolinder et al. (2007) were used to estimate $\mathrm{C}$ input to soil for different crops from harvest data (Table 2). Total aboveground biomass at harvest $(Y)$ was used for calculating $\mathrm{C}$ mass in total net primary production $(N P P)$ assuming a $\mathrm{C}$ concentration of $0.45 \mathrm{~g} \mathrm{~g}^{-1}$ in all plant parts

$$
N P P=0.45 \frac{Y}{1-R_{R E}}
$$

where $R_{R E}$ is the relative fraction of $\mathrm{C}$ allocation to roots including rhizodeposition, i.e., the sum of roots and rhizodeposits according to Bolinder et al. (2007). Values for $\mathrm{C}$ allocation to roots $\left(R_{R E}\right)$ are crop specific (Table 2), and were derived from root studies to $40 \mathrm{~cm}$ depth (median depth of all studies reviewed). In some of the reviewed studies, about $95 \%$ of the root biomass in small-grain cereals was found in the upper $30 \mathrm{~cm}$ of the soil. Since topsoil depth is considered as a variable in our study, the proportion of below-ground $\mathrm{C}$ input $\left(R_{R E} \times N P P\right)$ allocated to the topsoil has to be estimated. A Michaelis-Menten-type function was used to describe root distribution with depth $(z ; \mathrm{cm})$

$$
R_{m}(z)=\frac{z\left(z_{50}+z_{r}\right)}{z_{r}\left(z_{50}+z\right)}
$$

where $R_{m}$ is root mass fraction, $z_{r}$ is maximum rooting depth and $z_{50}$ is the depth to which $50 \%$ of the root mass is distributed. When setting $z_{r}=150 \mathrm{~cm}$ and $z_{50}=$ $10 \mathrm{~cm}, 71 \%$ of the roots are allocated to the upper 20 $\mathrm{cm}$ or $85 \%$ to the upper $40 \mathrm{~cm}$. This value corresponds well to the root distribution measured for small-grain cereals under similar soil and climatic conditions in Sweden (Hansson and Andrén, 1987; Kätterer et al., 1993). Since root allocation according to Bolinder et al. (2007) only accounts for root inputs to $40 \mathrm{~cm}$ depth, root input along the whole soil profile is underestimated by $15 \%$. Accounting for the remaining $15 \%$ root $\mathrm{C}$ below $40 \mathrm{~cm}, R_{R E}$ and, consequently, $N P P$ (eq. 5) have to be rescaled. Consequently, $\mathrm{C}$ input from roots including rhizodeposition $\left(I_{R E}\right)$ to equivalent soil depth was calculated as follows:

$I_{R E}=\frac{0.45 \times Y \times R_{m} \times R_{R E}}{1-\frac{R_{R E}}{0.85}}$

This parameter setting was used as a reference, but other parameter values were also tested (see below). In the bare fallow treatment, a constant root input of 40 $\mathrm{kg} \mathrm{C} \mathrm{ha}{ }^{-1}$ year $^{-1}$ from weeds was assumed.

For cereals, dry mass is reported separately for grains and straw, whereas for other crops, only total aboveground mass is reported. We estimated that $5 \%$ of the reported total aboveground mass was left in the field and considered as $\mathrm{C}$ input to the soil $\left(I_{S}\right)$. This value, which is lower than usually reported, is due to the fact that in our experiment aboveground biomass was cut close to the soil surface. For the three years for which harvest was not quantified due to crop failure (drought or heavy damage by birds), the $\mathrm{C}$ input was assumed to be $50 \%$ of the average input from two years before and two years after the crop failure.

2.8. Changes in soil $C$ stocks and humification of organic materials in soil 


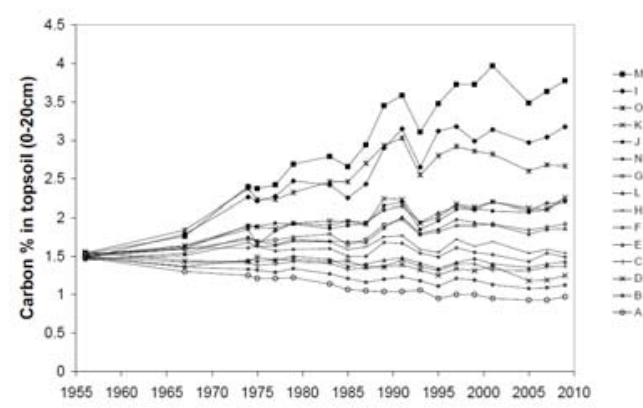

Fig. 2. Topsoil $(0-20 \mathrm{~cm})$ carbon concentrations over time in the Ultuna long-term soil organic matter experiment. Treatments (A to $\mathrm{O})$ are explained in Table 1 and are ordered according to the curves in the graph.

Linear and exponential functions were fitted to the time series of $\mathrm{C}$ stocks for each treatment with a fixed intercept corresponding to the $1956 \mathrm{C}$ stock at $0-20 \mathrm{~cm}$ depth (43.3 $\left.\mathrm{Mg} \mathrm{ha}^{-1}\right)$ by minimizing the sum of root mean squared errors (RMSE). The slopes of linear regression lines represent mean annual $\mathrm{C}$ stock changes $(\Delta C)$. If differences in $\Delta C$ were solely caused by $\mathrm{C}$ inputs, these two variables should be proportional. Accounting also for differences in quality of input, we assigned specific 'humification' coefficients $\left(h_{j}\right)$ to different input categories $(j=1 \ldots 7)$ characterizing the fraction of each input category that remains in the soil during the time considered here:

$\Delta C=\Delta C_{0}+\sum_{j=1}^{j=7} h_{j} I_{j}$

where $\Delta C_{0}$ corresponds to $\Delta C$ at zero input and $\sum h_{j} I_{j}$ $\left(\mathrm{Mg} \mathrm{ha}{ }^{-1}\right)$ is the sum of all fractions $\left(h_{j}\right)$ of mean annual $\mathrm{C}$ input $\left(I_{j}\right)$ of corresponding category in each treatment. The $h_{j}$-values were estimated by simultaneously solving the system of 15 equations (one for each treatment) by minimizing RMSE.

We also used a single-pool model based on firstorder kinetics for estimating humification coefficients $\left(H_{j}\right)$ by fitting the following model equation to the time series of $\mathrm{C}$ stocks $\left(C_{t}\right)$ for each treatment:

$C_{t}=\frac{\sum_{j=1}^{j=7} H_{j} I_{j}}{k}+\left(C_{0}-\frac{\sum_{j=1}^{j=7} H_{j} I_{j}}{k}\right) e^{-k t}$

where $C_{0}$ is the initial $\mathrm{C}$ stock in 1956 and $k$ is the decomposition rate constant (year ${ }^{-1}$ ) of soil organic C that was assumed to be the same in all treatments. The values for $H_{j}$ were estimated simultaneously for all treatments by minimizing RMSE. These $H_{j}$-values are not directly comparable with those estimated with the linear approach $\left(h_{j}\right)$ due to the different kinetics, which imply dependence of rates on actual $\mathrm{C}$ stocks in the first-order approach and also that the input is not entirely retained as in the linear approach but decomposing at the same rate $k$ as all other soil C.

\section{Results and discussion}

3.1. Changes in soil C concentrations and bulk densities

The measured differences in topsoil $\mathrm{C}$ concentrations due to the treatments are highly significant after the 53 years (Table 1). Between 1956 and 2009, topsoil C concentrations have decreased by more than a third in the bare fallow (treatment A) and more than doubled through peat $+\mathrm{N}$ fertilizer addition (treatment $\mathrm{M}$ ) (Fig. 2). The effects of other amendments than peat are less pronounced but still significant. The same applies to bulk density $(\rho)$, which is inversely correlated to C concentrations (Fig. 3). The slope of the regression line is very similar to that reported for other Swedish clay soils. The fact that those $\rho$-values on average were $0.15 \mathrm{~cm}^{3} \mathrm{~g}^{-1}$ lower than those for other Swedish clay soils with corresponding $\mathrm{C}$ content (Kätterer et al., 2006) can probably be ascribed to the absence of soil compaction due to manual tillage in our experiment. It is noteworthy that the two outliers below the regression line refer to treatments with the lowest pH-values (Table 1), i.e., ammonium sulfate (D) and sewage sludge (O).

The consistency of the analysis method for topsoil $\mathrm{C}$ concentration was tested by comparing it with data from an independent re-analysis of time series for five treatments, and showed no bias (Fig. 4). The slope of a linear regression forced through origo $(0 ; 0)$ was 1.006 and not significantly different from the 1:1 line. The slight overestimation of $\mathrm{C}$ concentrations in some samples were probably due to the fact that the reanalysis samples were taken one year after the application of amendments and compared to those taken two years after. Most measurements in Fig. 4 are based on the re-analysis of the same archived soil samples, so the relatively high variation around this regression line $\left(\mathrm{R}^{2}=0.90\right)$ would be due to the subsampling procedures of the old soil samples. Variability was generally higher at high $\mathrm{C}$ concentrations, and the sub-sampling errors are probably related to high-organic aggregates that are

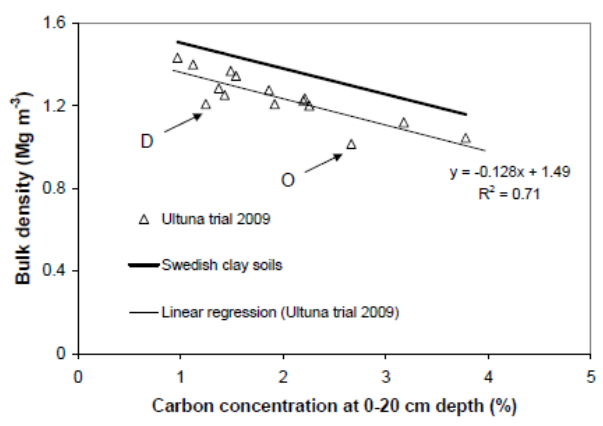

Fig. 3. Correlation between bulk density as a function of topsoil $(0-20 \mathrm{~cm})$ carbon concentrations in the Ultuna long-term soil organic matter experiment for 2009. For comparison, the correlation for 56 Swedish clayey topsoil horizons is shown (Kätterer et al., 2006). 


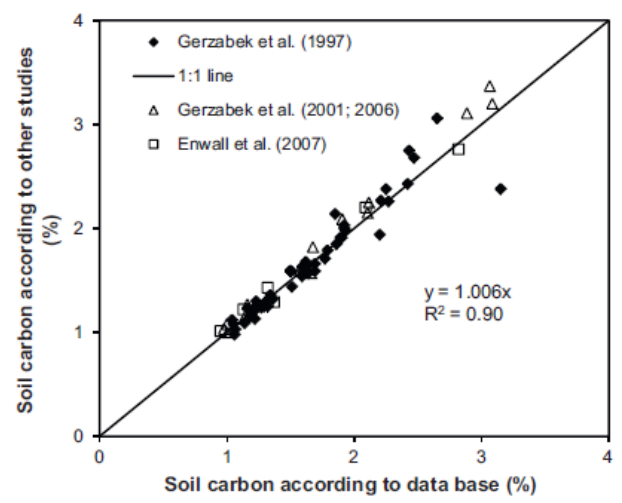

Fig. 4. Comparison between soil $\mathrm{C}$ concentrations recorded in our data base and from re-analysis of archived samples and from independent samplings. The regression $\mathrm{y}=1.006 \mathrm{x}\left(\mathrm{R}^{2}=0.90\right.$; filled diamonds; line not shown) concerns archived soil samples from five treatments between 1956 and 1993 that were reanalyzed in one batch (Gerzabek et al., 1997). Analysis reported from the other studies were from samples taken one year after the application of amendments (1994, 1998, 2000 and 2002) and are related to those on the abscissa recorded one year before, i.e., just before the bi-annual application of amendments. The average bias of these values from other studies was $0.08 \% \mathrm{C}$.

unevenly distributed within the soil. It is interesting to note that an increase in $\mathrm{C}$ concentration during one year in one analytical series appeared as a decrease in the other series. This observation is illustrating the problem with sub-sampling as exemplified by the outlier in figure $2(3.15 \% \mathrm{C}$ in our database), that was as low as $2.38 \% \mathrm{C}$ according to Gerzabek et al. (1997). Corresponding values before and after that particular outlier were lower or higher in the former or latter data series, respectively. Other C concentration measurements from independent samplings in 1994 and 1998 (Gerzabek et al., 2001), 2000 (Gerzabek et al., 2006) and 2002 (Enwall et al., 2007) closely followed the 1:1 line. Thus, we concluded that the $\mathrm{C}$ concentrations recorded in our database are free from severe methodological bias, in spite of the different methods and analytical equipment used over 53 years.

Bulk density measurements were available from the start in $1956\left(\rho=1.44 \mathrm{~g} \mathrm{~cm}^{-3}\right.$; Kirchmann et al., 1994) and from 1975, 1991 and 1997. The sampling in 1975 corresponded to the depth of $10-15 \mathrm{~cm}$ (Eriksson, 1980) whereas sampling in 1991 corresponded to $0-15 \mathrm{~cm}$ measured in two blocks only (Witter, 1996). Sampling in 1997 was limited to $2.5-$ $7.5 \mathrm{~cm}$ (Kirchmann and Gerzabek, 1999). In September 2009, two depths, 0-10 and 10-20 cm were sampled in all plots for bulk density determination. Since only the initial and final samplings corresponded to the whole $0-20 \mathrm{~cm}$ layer, we used data from these years to calculate annual values for each treatment. In addition, bulk density values were $11 \%$ lower at $0-10$ $\mathrm{cm}$ than at $10-20 \mathrm{~cm}$ depth according to measurements from 2009. Multiplying the values from 1997 with a factor 1.11 and using log-linear interpolation resulted in a slightly better correlation $(\mathrm{r}=0.90)$ than linear interpolation $(\mathrm{r}=0.88)$.

\subsection{Equivalent topsoil depth and carbon balance}

The mineral mass balance was calculated for estimating changes in equivalent topsoil depth as described above. The total amount of soil exported by sampling varied between $38 \mathrm{Mg} \mathrm{ha}^{-1}$ in treatment $\mathrm{O}$ and $48 \mathrm{Mg} \mathrm{ha}^{-1}$ in treatment $\mathrm{A}$. This corresponds to a surface subsidence of 3.1 and $3.4 \mathrm{~mm}$, respectively. The higher subsidence in A was due to the higher bulk density in this treatment. In terms of $\mathrm{C}$ export, fluxes were low and varying between $0.5 \mathrm{Mg}$ in $\mathrm{A}$ and 1.3 $\mathrm{Mg} \mathrm{C} \mathrm{ha}{ }^{-1}$ in $\mathrm{M}$ in total over 53 years.

Export of silica with harvested products was a minor flow and caused at maximum a subsidence of $1.1 \mathrm{~mm}$ in the sewage sludge treatment where yields were highest. The input of silica through sawdust and peat was negligible. These amendments increased surface elevation by 0.1 and $0.3 \mathrm{~mm}$, respectively. Straw and green manure addition increased elevation by $1.1 \mathrm{~mm}$ and manure by $2.5 \mathrm{~mm}$. The effect of minerals added with sewage sludge was considerably higher, $8.4 \mathrm{~mm}$.

Effects of bulk density changes largely overshadowed depth changes caused by mass fluxes. In the sewage sludge treatment, bulk density had decreased by almost $30 \%$ over the 53 years. This corresponds to about a $6.6 \mathrm{~cm}$ increase in elevation when taking changes in $\mathrm{C}$ concentrations and bulk densities in the different depths layers into account (Fig. 5). Since soil layers below $20 \mathrm{~cm}$ were denser and contained less $\mathrm{C}$, equivalent soil depth would have been greatly overestimated when using bulk densities and $\mathrm{C}$ concentrations solely for the upper $20 \mathrm{~cm}$ in the calculations (Fig. 5).

When summing up all mass fluxes according to equation 3 , the equivalent soil depth $\left(z_{\text {eq }}\right)$ varied between treatments from 19.5 to $27 \mathrm{~cm}$, which means that soil elevation increased by about $7 \mathrm{~cm}$ in the treatment with sewage sludge and decreased by $0.5 \mathrm{~cm}$ in the bare fallow (Table 1). The bare fallow (treatment A) was the only treatment where elevation decreased.

Direct elevation measurements, which were conducted to obtain an independent estimate of $z_{e q}$, revealed that differences between plots were highly variable due to the underlying topography of the field. Still, elevations between treatments with highest $\mathrm{C}$ concentrations in the topsoil differed significantly from those with lowest $\mathrm{C}$ concentrations (Table 2) according to analysis of variance. We consider the mass balance approach to be less uncertain than relative differences in plot elevation for calculating equivalent topsoil depth because bulk density, the major variable in the mass balance, was less variable between treatments than the elevation measurements (Table 1).

For most field experiments with 'more normal' plot sizes, mass loss due to soil sampling is negligible. So is generally also the export of mineral matter in harvested products (see above). However, 


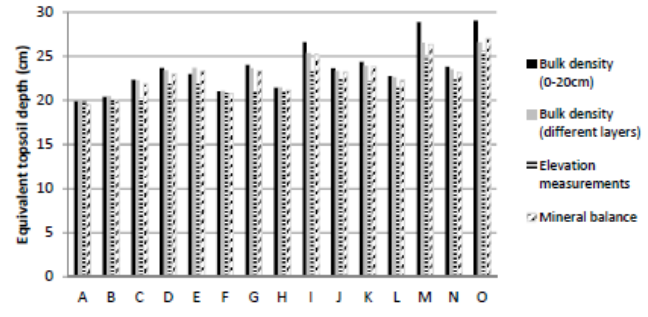

Fig. 5. Equivalent topsoil depth $\left(z_{e q}\right)$ calculated from detailed mineral mass balances compared with direct soil surface elevation measurements and two approaches based on bulk density and carbon concentrations in the different soil layers $(0-20,20-25$ and $25-30 \mathrm{~cm}$ depth) or extrapolated solely from measurements in the upper $20 \mathrm{~cm}$.

amendments with high ash content should be considered for calculating equivalent soil mass. Equivalent soil mass calculations based solely on bulk density and $\mathrm{C}$ concentrations in the upper $20 \mathrm{~cm}$ can result in biased estimates, by up to $10 \%$ in our experiment (Fig. 5; treatment M). However, when taking changes in $\mathrm{C}$ concentrations and bulk densities in the different depths layers into account, equivalent soil mass estimates will be less biased. The maximum bias using this method was $0.46 \mathrm{~cm}$ (in treatment $\mathrm{O}$ ) compared with the detailed mineral mass balance approach (Fig. 5).

Calculated topsoil C stocks in 2009 varied between 27 and $97 \mathrm{Mg} \mathrm{ha}^{-1}$ in bare fallow and peat $+\mathrm{N}$ (treatment $\mathrm{A}$ and $\mathrm{M}$ ), respectively (Table 1). Due to the negative correlations between bulk density and $\mathrm{C}$ concentrations or equivalent topsoil depths, relative differences in $\mathrm{C}$ concentrations and $\mathrm{C}$ stocks were similar. For example, the extreme treatments $\mathrm{A}$ and $\mathrm{M}$
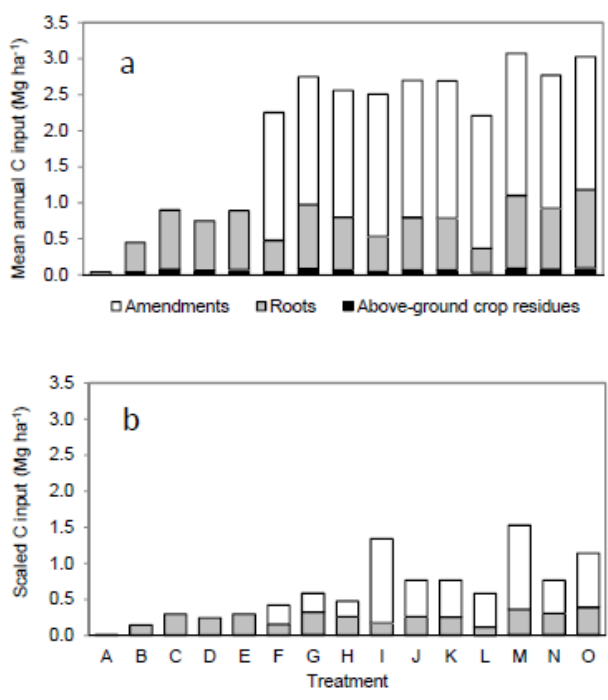

Fig. 6. Mean annual $\mathrm{C}$ inputs (a) and scaled $\mathrm{C}$ inputs (input $\times h_{j}$; b) in the 15 treatments through above-ground crop residues, roots including rhizodeposition to equivalent topsoil depth (1957-2008), and organic amendments (1956-2008). differed by factor 3.6 or 3.9 , correspondingly. The dynamics of $\mathrm{C}$ stocks were therefore similar to those for $\mathrm{C}$ concentrations (Fig. 2).

Total $\mathrm{C}$ inputs varied greatly between treatments, from almost nil in A to $3.1 \mathrm{Mg} \mathrm{ha}^{-1}$ year $^{-1}$ in $\mathrm{M}$ (Fig. 6). The total $\mathrm{C}$ input for the treatments was classified into categories with corresponding humification coefficients $\left(h_{j}\right)$. Solutions for $h_{j}$ according to equation 8 showed a very low scatter around the resulting regression line (Fig. 7). The intercept of the regression equation was $0.4 \mathrm{Mg} \mathrm{C}^{-1}$ year $^{-1}$, which implies that this amount of $\mathrm{C}$ is lost annually from this soil when the $\mathrm{C}$ input is zero. It also implies that the same amount of humified material (Ih) must be added annually to maintain steady-state. Straw amendment (treatment F) and green manure (treatment $\mathrm{H}$ ) was closest to this balance. In accordance with previous studies (Andrén and Kätterer, 1997), the humification coefficient was highest for peat, followed by sewage sludge, sawdust and farmyard manure. The green manure coefficient was lower than that of average aboveground crop residues.

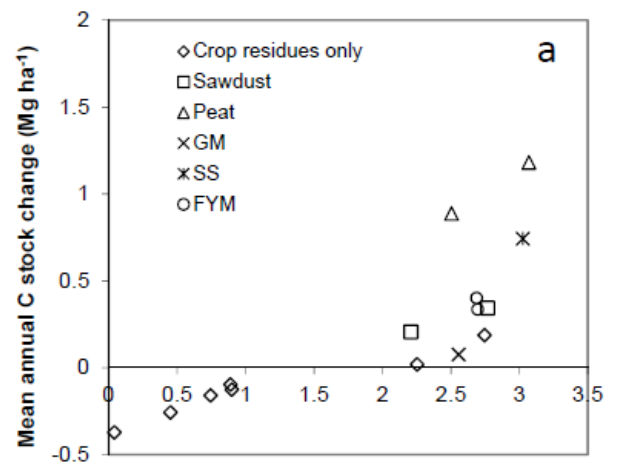

Mean annual $\mathrm{C}$ input $\left(\mathrm{Mg} \mathrm{ha}^{-1}\right)$

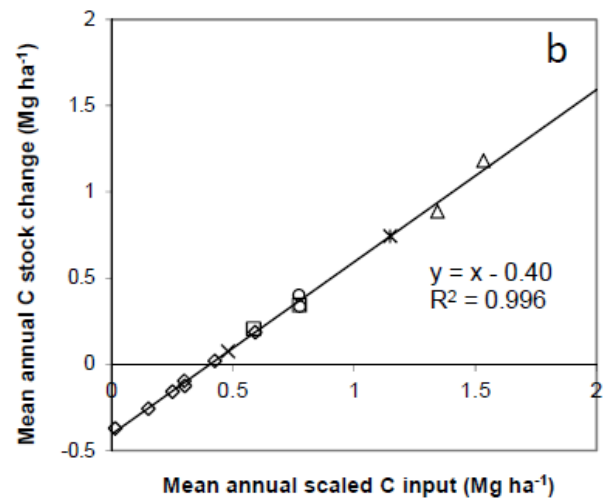

Fig. 7. Mean annual $\mathrm{C}$ stock change in the topsoils to equivalen depth of the fifteen treatments as a function of mean annual $\mathrm{C}$ input (a) or mean annual scaled $\mathrm{C}$ input $\left(\sum h_{j} I_{j}\right.$ in equation $\left.8 ; \mathrm{b}\right)$ The scaling was done by assigning a certain value $\left(h_{j}\right)$ to each $C$ input category, i.e., above-ground crop residues and added straw (Shoots), roots including rhizodeposition, farmyard manure (FYM), peat, sewage sludge (SS), sawdust (SD) and green manure (GM). 
The new and interesting results from the current investigation is that the calculated humification for root-derived $\mathrm{C}$ was similar to that of sewage sludge and about 2.3 times higher than that of aboveground plant material (Fig. 7). In fact, the estimated $h$ value of 0.35 for root-derived $\mathrm{C}$ was somewhat higher compared to those estimated in situ from other longterm field experiments. For example, in a 12-year field experiments with maize in the U.S.A. considering a soil depth of 0-17 cm, Barber (1979) found that the proportion of root-derived maize residues retained as soil organic matter ranged from 18 to $23 \%$. Similarly, two long-term field experiments (22 and 25 years, respectively) examined by Plénet et al. (1993) in France showed that root-derived $\mathrm{C}$ for maize ranged from 22.5 to $30 \%$ at the 'Serreslous' site $(0-25 \mathrm{~cm})$, and 16 to $21 \%$ at the 'Doazit' site $(0-23 \mathrm{~cm})$.

Calculations based on first-order kinetics (equation 9) resulted in the exactly the same conclusion, namely that humification of root-derived material was 2.3 times higher that of aboveground plant material (Table 4). The fit of the first-order model to the time series of $\mathrm{C}$ stock measurements was not significantly higher than that of the linear. RMSEs were 2.3 and $2.4 \mathrm{Mg} \mathrm{C}^{-1}$, respectively, on average over all treatments. Naturally, the estimated humification coefficients $\left(H_{j}\right.$; equation 9) where slightly higher according to the first-order approach since $\mathrm{C}$ inputs are not entirely retained as in the linear approach but decomposed at the same rate ( $k$; equation 9) as all other soil C (Table 4). The decomposition rate constant ( $k$; equation 9) was assumed to be constant in all treatment and its estimated value was 0.011 year $^{-1}$. Accounting for differences in abiotic conditions between treatments, we also tested to adjust $k$ approximately to crop yields, i.e., assuming higher values in bare fallow and low-yielding treatments than in those with high yields due to higher soil temperatures and lower evapotranspiration in the lowyielding treatments, but this did not affect our main conclusion regarding humification of roots. This abiotic effect on $k$ caused by vegetation was probably also counterbalanced by higher soil porosity in high yielding treatments which induces higher soil water holding capacity and less frequent water stress for decomposers.

In a review on the relative contribution of root versus shoot material to soil organic matter formation, Rasse et al. (2005) concluded that results from in situ experiments indicate that root contribution to soil organic $\mathrm{C}$ per unit $\mathrm{C}$ is, on average, 2.4 times higher than of shoots. Data ranged from a minimum of 1.5 to a maximum of 3.7, compiling results from maize, hairy vetch and alfalfa. However, in the review by Rasse et al. (2005), and studies by Barber (1979) and Plénet et al. (1993), it was assumed that the annual input of fresh root $\mathrm{C}$ through root exudation, turnover and cell sloughing into soil was equivalent to that of the 'measurable root biomass' (i.e. 100\%). In the calculation by Bolinder et al. (2007), root exudation, turnover and cell sloughing was assumed to be $65 \%$ of the measurable root biomass. This is consistent with results from a long-term (1979-88) project on agroecosystems under Swedish conditions, Ecology of arable land - the role of organisms in $N$ cycling by Andrén et al. (1989). Using an estimate similar to that of the other authors would have resulted in lower $h$ values for root-derived $\mathrm{C}$, but our calculated root humification coefficient would still remain as high as 0.29 . However, the calculations rely on the assumption that rhizosphere-deposited $\mathrm{C}$ behaves similarly to $\mathrm{C}$ in the 'measurable root biomass'. This assumption is difficult to test experimentally, but it definitely needs to be further addressed.

When comparing different studies we are also facing the possible errors caused by the fact that different $\mathrm{C}$ concentrations and ash corrections are used for calculations. When no measurements are made, authors are typically assigning a $\mathrm{C}$ concentration in crop residues in the range of 0.40 to $0.50 \mathrm{~g} \mathrm{~g}^{-1}$, most often $0.45 \mathrm{~g} \mathrm{~g}^{-1}$. In the current study, Bolinder et al. (2007) used 0.45, Plénet et al. (1993) used measured values ranging from 0.42 to 0.44 , while the calculations by Barber (1979) was made assuming a C concentration of $0.40 \mathrm{~g} \mathrm{~g}^{-1}$. For national greenhouse gas inventories a default value of $0.5 \mathrm{~g} \mathrm{~g}^{-1}$ (no ash correction) is proposed (IPCC, 2006).

\subsection{Sensitivity analysis}

Estimates of annual $\mathrm{C}$ inputs to soil from roots are associated with substantial uncertainties even when rhizo-deposited root $\mathrm{C}$ is excluded in calculations. The mean shoot-to-root ratio used to derive the physical amount of 'measurable root biomass' in the allometric functions for small-grain cereals by Bolinder et al. (2007) had a coefficient of variation as high as $50 \%$. Furthermore, it may be argued that assuming constant root/shoot ratios irrespective of production level, as done in this study, may not be realistic. Indeed, most research before the late 1970s has shown that a constant positive correlation between shoots and roots does not exist (Böhm, 1979). For example Welbank et

Table 4. Humification coefficients estimated with the first-order kinetics approach $\left(H_{j}\right)$ or linear approximation $\left(h_{j}\right)$ and sensitivity to changes in allometry used for calculating $\mathrm{C}$ inputs derived from above- and below-ground crop residues. 'Reference' scenarios refer to the linear regression model as shown in figure 7 . In scenario I, root inputs were increased by a factor 2.3 in all treatments. In scenario II, shoot input was tripled and in scenario III, root input was the same as in treatment $\mathrm{O}$ as in the reference scenario (highest root production), but scaled for the other treatments so that the root/shoot ratio increased with decreasing production levels (up to a factor 3 ). In scenario IV, root production was the same as in treatment $\mathrm{O}$ in all treatments except $\mathrm{A}$, irrespectively of production level.

\begin{tabular}{|c|c|c|c|c|c|c|}
\hline & \multirow{2}{*}{\begin{tabular}{|l|} 
First \\
order
\end{tabular}} & \multirow{2}{*}{ Reference- } & \multicolumn{4}{|c|}{ Scenario } \\
\hline & & & I & II & III & IV \\
\hline$h_{\text {Shoot }}$ & 0.17 & 0.15 & 0.15 & 0.15 & 0.15 & 0.13 \\
\hline$h_{\text {Root }}$ & 0.39 & 0.35 & 0.15 & 0.32 & 0.23 & 0.18 \\
\hline$h_{\text {Farmyard manure }}$ & 0.32 & 0.27 & 0.27 & 0.27 & 0.26 & 0.26 \\
\hline$h_{\text {Peat }}$ & 0.71 & 0.59 & 0.59 & 0.59 & 0.61 & 0.59 \\
\hline$h_{\text {Sewage sludge }}$ & 0.54 & 0.41 & 0.41 & 0.41 & 0.49 & 0.47 \\
\hline$h_{\text {Sawdust }}$ & 0.3 & 0.25 & 0.25 & 0.25 & 0.25 & 0.22 \\
\hline$h_{\text {Green manure }}$ & 0.15 & 0.12 & 0.12 & 0.12 & 0.12 & 0.12 \\
\hline RMSE & not & 0.02 & 0.02 & 0.02 & 0.04 & 0.06 \\
\hline$R^{2}$ & relevant & $\mathrm{t} \quad 1.00$ & 1.00 & 1.00 & 0.98 & 0.97 \\
\hline
\end{tabular}


al. (1974) found that the shoot-to-root ratio for unfertilized barley and oats were almost half as that of fertilized cereals. Similar results were reported for a barley crop with and without $\mathrm{N}$ fertilization in Sweden by Paustian et al. (1997). As an alternative to a linear approach, Saffih-Hdadi and Mary (2008) considered a minimum root biomass in their estimations.

We tested the sensitivity of the assumptions underlying the allometric functions by changing root/shoot ratios depending on net primary production (Table 4). The main hypothesis tested in this paper that roots contribute relatively more to refractory soil organic matter than aboveground residues, could be falsified if below-ground $\mathrm{C}$ inputs would have been underestimated by a factor of at least 2.3 (Scenario I; Table 4). A tripling of aboveground $\mathrm{C}$ input would affect $h_{\text {Root }}$ only marginally (scenario II). The effect of decreasing root/shoot ratios with increasing net primary production was tested in scenarios III and IV. Root mean squared errors (RMSE) for these assumptions increased sharply, at least indicating that the hypotheses behind these two scenarios are likely to be false. Humification coefficients for the amendments were only marginally affected by changes in root/shoot ratios and illustrate the low correlation between parameters in our approach. Therefore it is unlikely that root input was significantly underestimated. We conclude that there is strong evidence from this experiment that roots contribute more to relatively stable soil $\mathrm{C}$ pools than the same amount of shoot-derived plant material does.

\section{Acknowledgements}

The experiment was initiated and planned by the late Olle Gunnarsson and late Hans Nömmik working for the governmental organization 'Statens Jordbruksförsök'. In 1974, the trial was threatened with closure. Due to the great interest of Prof. Jan Persson, who recognized the value and potential of this experiment, its maintenance was continued and the responsibility for the management was taken by the Department of Soil Science. Thanks to his far-sightedness and continued interest, the trial has become one of the most investigated long-term arable field experiment in Sweden. Over the last 20 years, the experiment has been carefully managed by Pär Hillström.

\section{References}

Andrén, O., Kätterer, T., 1997. ICBM - the Introductory Carbon Balance Model for exploration of soil carbon balances. Ecol. Appl. 7, 1226-1236.

Andrén, O., Kirchmann, H., Kätterer, T., Magid, J., Paul, E.A., Coleman, D.C., 2008. Visions of a more precise soil biology. Eur. J. Soil Sci. 59, 380-390.

Andrén, O., Lindberg, T., Boström, U., Clarholm, M., Hansson, A-C., Johansson, G., Lagerlöf, J., Paustian, K., Persson, J., Pettersson, R., Schnürer, J., Sohlenius B., Wivstad, M., 1989. Chapter 5. Organic carbon and nitrogen flows. In: Andrén, O., Lindberg, T., Paustian, K.,
Rosswall, T. (Eds.), Ecology of arable land - organisms, carbon and nitrogen cycling. Ecol. Bull. (Copenhagen) 40, 85-125.

Barber, S.A., 1979. Corn residue management and soil organic matter. Agron. J. 71, 625-627.

Barré, P., Eglin, T., Christensen, B.T., Ciais, P., Houot, S., Kätterer, T., van Oort, F., Peylin, P., Poulton, P.R., Romanenkov, V., Chenu, C., 2010. Quantifying and isolating stable soil organic carbon using long-term bare fallow Biogeosci. 7, 3839-3850.

Bergkvist, P., Jarvis, N., Berggren, D., Carlgren, K., 2003. Long-term effects of sewage sludge applications on soil properties, cadmium availability and distribution in arable soil. Agr. Ecosyst. Environ. 97, 167-179.

Boiffin, J., Keli Zaghabi, J., Sebilotte, M., 1986. Système de culture et statut organique des sols dans le Noyonnais: application du modèle de Hénin-Dupuis. Agron. 6, 437446.

Bolinder, M.A., Angers, D.A., Giroux, M., Laverdière, M.R., 1999. Estimating C inputs retained as soil organic matter from corn (Zea Mays L.). Plant Soil 215, 85-91.

Bolinder, M.A., Janzen, H.H., Gregorich, E.G., Angers, D.A., VandenBygaart, A.J., 2007. An approach for estimating net primary productivity and annual carbon inputs to soil for common agricultural crops in Canada. Agr. Ecosyst. Environ. 118, 29-42.

Böhm, W., 1979. Methods of studying root systems. Springer-Verlag, $188 \mathrm{pp}$.

Delas, J., Molot, C., 1983. Effet de divers amendements organiques sur les rendements du maïs et de la pomme de terre cultivés en sol sableux. Agron. 3, 19-26.

Enwall, K., Nyberg, K., Bertilsson, S., Cederlund, H., Stenström, J., Hallin, S., 2007. Long-term impact of fertilization on activity and composition of bacterial communities and metabolic guilds in agricultural soil. Soil Biol. Biochem. 39, 106-115.

Eriksson, J., 1980. Inverkan på markstrukturen av olika kvävegödselmedel och organiskt material. Swedish University of Agricultural Sciences, Dept. of Soil Sciences, Division of Soil Fertility, Report 129.

FAO, 1989. Soil map of the world. ISRIC, Technical Paper 20, Wageningen, The Netherlands.

Filya, I., 2004. Nutritive value and aerobic stability of whole crop maize silage harvested at four stages of maturity. Anim. Feed Sci. Tech. 116, 141-150.

Fontaine, S., Barot, S., Barre, P., Bdioui, N., Mary, B., Rumpel, C., 2007. Stability of organic carbon in deep soil layers controlled by fresh carbon supply. Nature 450, 227 280 .

Gerzabek, M.H., Pichlmayer, F., Kirchmann, H. Haberhauer, G., 1997. The response of soil organic matter to manure amendments in a long-term experiment at Ultuna, Sweden. Eur. J. Soil Sci. 48, 273-282.

Gerzabek, M.H., Haberhauer, G., Kirchmann, H., 2001. Soil organic matter pools and carbon-13 natural abundances in particle-size fractions of a long-term agricultural field experiment receiving organic amendments. Soil Sci. Soc. Am. J. 65, 352-358.

Gerzabek, M.H., Antil, R.S., Kögel-Knabner, I., Knicker, H., Kirchmann, H., Haberhauer, G., 2006. How are soil use and management reflected by soil organic matter characteristics: a spectroscopic approach. Eur. J. Soil Sci. 57, 485-494

Grace, P.R., Ladd, J.N, Robertson, G.P., Gage, S.H., 2006. SOCRATES - A simple model for predicting long-term 
changes in soil organic carbon in terrestrial ecosystems. Soil Biol. Biochem. 38, 1172-1176.

Hadders, G., Arshadi. M., Nilsson. C., Burvall. J., 2001. Bränsleegenskaper hos spannmålskärna. JTI - Institutet för jordbruks- och miljöteknik. Rapport 289.

Hansson, A-C., Andrén, O., 1987. Root dynamics in barley, meadow fescue and lucerne, investigated with a minirhizotron technique. Plant Soil 103, 33-38.

Hansson, A-C., Steen, E., 1984. Methods of calculating root production and nitrogen uptake in an annual crop. Swed. J. Agric. Res. 14, 191-200.

Hénin, S., Dupuis, M., 1945. Essai de bilan de la matière organique du sol. Ann. Agron. 15, 17-29.

Hyvönen, R., Ågren. G.I., Andrén, O., 1996. Modelling longterm carbon and nitrogen dynamics in an arable soil receiving organic matter. Ecol. Appl. 6, 1345-1354.

IPCC, 2006. 2006 IPCC Guidelines for National Greenhouse Gas Inventories, Prepared by the National Greenhouse Gas Inventories Programme, Eggleston, H.S., Buendia, L., Miwa, K., Ngara, T. and Tanabe, K. (Eds), IGES, Japan

IPCC, 2007. Climate Change 2007: Mitigation. Contribution of Working Group III to the Fourth Assessment Report of the Intergovernmental Panel on Climate Change. Cambridge University Press, Cambridge and New York.

Jackson, M.G., 1977. Review article; the alkali treatment of straws. Anim. Feed Sci. Tech. 2, 105-130.

Janssen, B.H., 1984. A simple method for calculating decomposition and accumulation of 'young' soil organic matter. Plant Soil 76, 297-304

Jenkinson, D.S., Johnston, A.E., 1976. Soil organic matter in the Hoosfield continuous barley experiment. Rothamsted Experiment Station Report for 1976, Part 2. Harpenden, UK, pp. 87-101.

Jenkinson, D.S., Harkness, D.D., Vance, E.D., Adams, D.E., Harrison, A.F., 1992. Calculating net primary production and annual input of organic matter tor soil from the amount and radiocarbon content of soil organic matter. Soil Biol. Biochem. 24, 295-308.

Jensen, A., Dam-Johansen, K., Wójtowicz, M.A., Serio, M.A., 1998. TG-FTIR study of the influence of potassium chloride on wheat straw pyrolysis. Energ. Fuel. 12, 929938.

Johnson, J.M-F., Allmaras, R.R., Reicosky, D.C., 2006. Estimating source carbon from crop residues, roots and rhizodeposits using the national grain-yield database. Agron. J. 98, 622-636.

Jones, L.H.P, Handreck, K.A., 1967. Silica in soils, plants and animals. Adv. Agron. 19, 107-149.

Juston, J., Andrén, O., Kätterer, T., Jansson P-E., 2010. Uncertainty analyses for calibrating a soil carbon balance model to agricultural field trial data in Sweden and Kenya. Ecol. Model. 221, 1880-1888.

Kätterer, T., Andrén, O., 1999. Long-term agricultural field experiments in Northern Europe: Analysis of the influence of management on soil carbon stocks using the ICBM model. Agr. Ecosyst. Environ. 72, 165-179. Erratum: Agr. Ecosyst. Environ. 75, 145-146.

Kätterer, T., Hansson, A-C., Andrén, O., 1993. Wheat root biomass and nitrogen dynamics - effects of daily irrigation and fertilization. Plant Soil 151, 21-30.

Kätterer, T., Andrén, O., Jansson, P-E., 2006. Pedotransfer functions for estimating plant available water and bulk density in Swedish agricultural soils. Acta Agr. Scand. 56, 263-276.

Kirchmann, H., Gerzabek, M.H., 1999. Relationship between soil organic matter and micropores in a long-term experiment at Ultuna, Sweden. J. Plant Nutr. Soil. Sci. 162, 493-498.

Kirchmann, H., Pichlmayer, F., Gerzabek, M.H., 1996, Sulfur balances und Sulfur-34 abundance in a long-term ferilizer experiment. Soil Sci. Soc. Am. J. 59, 174-178.

Kirchmann, H., Persson, J., Carlgren, K., 1994. The Ultuna long-term soil organic matter experiment, 1956-1991. Department of Soil Sciences, Reports and Dissertations 17. Swedish University of Agricultural Sciences, Uppsala, Sweden.

Kirchmann, H., Pilchmayer, F., Gerzabek, M.H., 1996. Sulfur balance and sulfur-34 abundance in a long-term fertilizer experiment. Soil Sci. Soc. Am. J. 60, 174-178.

Knorr, M., Frey, S.D., Curtio, P.S., 2005. Nitrogen additions and litter decomposition: a meta analysis. Ecol. 86, 32523253.

Lal, R., 2009. Challenges and opportunities in soil organic matter research. Eur. J. Soil Sci. 60, 158-169.

Lal, R., Follett. F., 2009. Priorities in soil carbon research in response to climate change. In: Lal, R., Follett, F. (Eds.), Soil Carbon Sequestration and the Greenhouse Effect. SSSA Special Publication 57, second edition.

Lanning, F.C., Hopkins, T.L., Lorea, J.C., 1980. Silica and Ash Content and Depositional Patterns in Tissues of Mature Zea mays L. Plants. Ann. Bot. 45, 549-554.

Larson, W.E., Clapp, C.E., Pierre, W.H., Morachan, Y.B., 1972. Effects of increasing amounts of organic residues on continuous corn: II. Organic carbon, nitrogen, phosphorus and sulfur. Agron. J. 64, 204-208.

Linères, M., Djakovitch, J.L., 1993. Characterization of the biological stability of organic inputs by biochemical analysis. In: J. Decroux, J.C. Ignazi (Eds.). Organic matter and agriculture: Fifth Forum on RationalFertilization, pp. 159-168. Paris, France: Gemas, Comifer.

Nye, P.H., Greenland, D.J., 1964. Changes in the soil after clearing tropical forest. Plant Soil 21, 101-112.

Olanders, B., Steenari, B-M., 1995. Characterization of ashes from wood and straw. Biomass Bioenerg. 8, 105-1 15.

Pan, X., Sano, Y., 2005. Fractionation of wheat straw by atmospheric acetic acid process, Bioresource Technol. 96, 1256-1263.

Tremblay, M-E., Nduwamungu, C., Parent, L.E., Bolinder, M.A., 2010. Biological stability of carbon and nitrogen in organic products and crop residues using FourierTransform Near-Infrared reflectance spectroscopy. Commun. Soil Sci. Plan. 41, 917-934.

Parton, W.J., Persson, J., Anderson, D.W., 1983. Simulation of organic matter changes in Swedish soils. In: Laurenroth, W.K., Skogerboe, G.V., Flug, M. (Eds.), Analysis of ecological systems: state-of-the-art in ecological modeling. Elsevier, Amsterdam, The Netherlands, pp. 511-516.

Paustian, K., Andrén, O., Clarholm, M., Hansson, A-C., Johansson, G., Lagerlöf, J., Lindberg, T., Pettersson, R., Sohlenius, B., 1990. Carbon and nitrogen budgets of four agroecosystems with annual and perennial crops, with and without nitrogen fertilization. J. Appl. Ecol. 27, 60-84.

Paustian, K., Parton. W.J., Persson, J., 1992. Modeling soil organic matter in organic-amended and nitrogen-fertilized long-term plots. Soil Sci. Soc. Am. J. 56, 476-488.

Persson, J., Kirchmann, H., 1994. Carbon and nitrogen in arable soils as affected by supply of $\mathrm{N}$ fertilizers and organic manures. Agric. Ecosyst. Environ. 51, 249-255.

Petersen, B. M., Berntsen, J., Hansen, S., Jensen L.S., 2005. CN-SIM - a model for the turnover of soil organic matter. I. Long-term carbon and radiocarbon development. Soil Biol. Biochem. 37, 359-374. 
Plénet, D., Lubet, E., Juste, C., 1993. Évolution à long terme du statut carboné du sol en monoculture non irriguée du maïs (Zea mays L.). Agron. 13, 685-698.

Pribyl, D.W., 2010. A critical review of the conventional SOC to SOM conversion factor. Geoderma 156, 75-83.

Rasse, D.P., Rumpel, C., Dignac, M-F., 2005. Is soil carbon mostly root carbon? Mechanisms for a specific stabilization. Plant Soil 269, 341-356.

Saffih-Hdadi, K., Mary, B., 2008. Modeling consequences of straw residues export on soil organic carbon. Soil Biol. Biochem. 40, 594-607.

Sander, B., 1997. Properties of Danish biofuels and the requirements for power production. Biomass Bioenerg. 12, 177-183.

Welbank, P.J., Gibb, M.J., Taylor, P.J., Williams, E.D., 1974. Root growth of cereal crops. Rothamsted Experimental Station Report, 1973, Part 2, pp. 26-66.

Wilhelm, W.W., Johnson, J.M.F., Hatfield, J.L., Voorhees, W.B., Linden, D.R., 2004. Crop and soil productivity response to corn residue removal: A literature review. Agron. J. 96, 1-17.

Witter, E., 1996. Soil C balance in a long-term field experiment in relation to the size of the microbial biomass. Biol. Fertil. Soils 23, 33-37. 